\title{
The Application of Computer Technology on Teaching Management in Colleges and Universities
}

\author{
Da Yang ${ }^{1, a^{*}}$ and Shijun $\mathrm{Li}^{2, \mathrm{~b}}$ \\ ${ }^{1}$ Jilin Agricultural University, Jilin, China \\ ayangnan1983116@163.com, ${ }^{\mathrm{b}} 452835889 @ q q . c o m$
}

\section{Keywords: Teaching management; Management concept; Computer technology}

\begin{abstract}
The modernization of teaching management is the inevitable developing trend of the current teaching management with the development of science and technology and the continuous expansion of teaching in colleges and universities. The teaching management personnel should constantly update management concept. To improve working methods is prerequisite to enhance the quality of teaching, to improve management level is an effective way to realize the talent cultivation and development in colleges and universities. The application of computer technology has become the requirement of the modernization of the teaching management in colleges and universities. This paper expounds on that the computer technology plays an important part in college teaching management and how to strengthen computer technology application in university teaching management.
\end{abstract}

\section{Introduction}

Teaching management is the core of the management in colleges and universities, and it is the guarantee which can carry out teaching plan and training objectives. The mission of the teaching management staff grows increasingly with the continuous development of science and technology, especially the wide application of computer network technology. The personnel not only should master the modern means of management but also constantly update management concept, make the teaching management be with standardization, institutionalization and scientific. At the same time, establish and develop a number of highly qualified teaching management teams as one of the vigorous development of long-term planning.

\section{Computer Technology Plays Important Part in College Teaching Management}

In recent years, there are heavy workloads of teaching information analysis of university educational administration department due to the continuous reform of college teaching management system and cultivation mechanism of students, schools are more diversified. Traditional way of teaching management has not adapted to the development of university education management situation and the needs of the work. Therefore, personnel must use computer and network information technologies, grope a kind of modernization and scientific pattern of university teaching management. The application of computer technology has become the requirement of the modernization of the teaching management in colleges and universities.

Teaching management controls various aspects of school teaching information resources management in order to maintain normal operation of the school teaching work. All kinds of information of teaching educational administration and data can analyze the teaching status, evaluation of teaching quality and teaching management decisions, need to be stored and comprehensive scientific processing. This traditional way of working is unsustainable and multifarious for vast amounts of data. The application of computer technology is easy to realize. Educational administration management modernization is on the application of the computer. 


\section{Computer Application Problem of Teaching Management in Colleges and Universities}

As you can see, computer technology has a broad application prospect in college teaching management. But at present our country's colleges and universities teaching management still exist many problems in this respect.

\section{Weak Viewpoint of Teaching Management}

Education idea decides education consciousness and action, each thought of the teaching management work and working method. At present, the education process is more emphasis on the teaching reform of computer technology while ignoring the modernization of teaching management. On the teaching management, people are still accustomed to the traditional management ideas, theories and methods, accustomed to using the traditional way of information construction, management and exchange, stay on the indicated teaching management mode and method.

\section{The Business Quality of Teaching Management Personnel is Not High}

Due to the insufficient understanding of the importance about college teaching management team, people think that teaching management is transactional work and anyone can do the work for a long time. They ignore the selection and train of teaching management. A considerable part of the teaching management personnel lack management expertise and computer skills, personnel solve the problem only by traditional experience management, they are in transaction management and daily affairs all day. Teaching construction of management team has been lagging behind the construction of teacher team.

\section{Poor Software Applicability of Teaching Management}

There are various types of teaching management software, but it is difficult to find a suitable for all the software. Especially many colleges and universities are in the transition period. The software design applicability is not strong of teaching management software that many teachers' enthusiasm is not high.

\section{Change the Traditional Ideas}

Modern teaching management is based on computer as the means, use modern information network technology and management methods. Personnel should attaches great importance to the management of high quality and high efficiency, pursuit informatization and network of teaching resource management. All teaching management staffs should change the traditional management ideas, master and make full use of modern network management technology, improve the efficiency of management. At the same time, the university should advocate the educational administration system to the teachers and students. The specific implementation of modern teaching management, not only requires them to have the basic knowledge of computer and network technology, also have the capability of simple and easy operation.

\section{Improve the Quality of Personnel and Complete the Labor of Duty}

There is an important premise is that the teaching management staff to improve their own quality. Teaching management work for a long time in the first line of teaching management what is not only the leadership among personnel, it is also a link between schools, teachers and students. The inspection on teacher's teaching work, evaluation, assessment and feedback decided the importance of the work. The validity of teaching management is depending on the thought level and knowledge skill and personal accomplishment of teaching management. Therefore the personnel should 
constantly update their knowledge, learn computer network technology, pedagogy, management, psychology and other knowledge. They not only should expand aspect of knowledge, but also the further study of education theory, master the law of higher education, set up following the era pulse of ideology and the concept of education. In addition, management personnel grassroots level and the teaching line at ordinary times, understand the status of teaching and learn between teachers and students, etc., and master the first-hand materials, timely process and feedback the problems which existing in the teaching and learning, to make the school teaching work more orderly and effectively.

\section{Strengthen the Construction of Teaching Management Team}

The university must strengthen the team construction in order to realize the computerization and informationization of teaching management. To improve the personnel management skills and the ability of using computer. Network teaching management environment put forward higher request for teaching management team. Teaching management personnel must understand modern education teaching idea, master management science, information science, management experience and innovation ability. The staff can become skilled, complex and innovative teaching management personnel with high quality. Only improve the teaching management of modern computer technology application ability, improve the ability of the acquisition, analysis, and process information, in order to adapt to the needs of the development of college teaching management information.

\section{Strengthen the Professional Training of Teaching Management}

Scientific, standardized and orderly high level of teaching management can ensure the normal conduct of school teaching work. But college teaching management, especially the teaching director-general are busy all day long and have complex daily affairs. It is difficult to take time for self charging, professional training, teaching reform and research. The teaching management staff has a little chance to business study, training, communication, teaching management inevitably caught in a vicious circle of low efficiency. The teaching management department is an important service window of the school, schools should be like the training teachers, build system of management personnel training, the university cannot named the daily meeting for the teaching management personnel training, they should adopt flexible and varied, targeted training for different jobs and different individual management. The university also can take academic education, expand the ability training, knowledge update business training, research and training. They also can invite experts to do seminar, a teaching seminar or sent out teaching management staff to study, let its collection, draw lessons from the beneficial experience of teaching management reform and practice both at home and abroad, exploration and education reform, development and adapt to knowledge economy era of the new way of teaching management in colleges and universities.

\section{Change the Teaching Management Function}

The university should strengthen the application of computer technology in college teaching management, must change the teaching management function, establish a corresponding system of teaching management. The direction of the teaching reform of management system, which is mainly composed of faculty management efforts should be made to establish the teaching management system. Enlarge the autonomy of college teaching management, strengthen information feedback function, improve information monitoring of daily teaching activities and reaction ability. Through the reform of teaching management system, teaching management functions from the original omni-directional, the whole program of project management to macroeconomic regulation and 
control and enhanced services, is committed to teaching management computerization and networking.

\section{Strengthen the Management of Teaching Supervision System}

The universities can establish reasonable and incentive mechanism of teaching management and supervision system what are to strengthen the teaching management, improve the quality of teaching to become an important guarantee. Therefore, to establish a set of public office system, the teaching management staff's job responsibilities, job requirements, procedures and service purpose of the public in the office door, release supervision telephone, set up a complaint box, consciously accept the supervision of the staff and students.

\section{Conclusion}

To sum up, the areas of teaching management can be charged using the computer to management in colleges and universities. In today's education modernization, it is sensitive to establish efficient teaching management information system which make full use of the computer's help. Make the argument decision-making to be scientific, democratization, improve the accuracy of management, so as to improve the efficiency of management.

\section{References}

[1] Jonathan W. Palmer. Web site usability, design, and performance metrics [J]. Information Systems Research, 2008, 13(2): 151-167.

[2] Ritu Agarwal Assessing a firm's Web presence: A heuristic evaluation procedure for the measurement of usability [J].Information System Research, 2008, 3(2): 168-186.

[3] Tomas C. Almind, Perer Ingwersen. Information analysis on the world wide web: method lolgical approaches to webmetrics'[J] Journal of Dongnan IUniversity. 2007. 15(5): 25-27. 